\title{
Targeted Training in Light of the Biomechanical Analysis for the Skill of (Lift) and Its Impact on the Physical Level for Aerobic Dance Gymnasts
}

\section{DR. Naser mohammed Helmy El hanafy \\ DR . Atteyat Mohamed Mohamed El sayed}

\begin{abstract}
- Introduction and Research Problem:
Gymnastic sport has witnessed a great development in technical performance for its different types and the law related to each type of gymnastics have developed, whereas among the most important of these types is aerobic due to what it enjoys of aesthetic, physical, and kinetic significance and proliferation of countries that practice it and seek to achieve advance position in the international championships.
\end{abstract}

Aerobic dance gymnastics is at the forefront of sports activities that have received a large share of new innovations in the arts of kinetic performance, which led to the emergence of a significant number of innovative skills for aerobic dance gymnastics.

Adel Abdul-Basir (1998 AD) indicates that the scientific evidences have demonstrated that the techniques of extreme performance of gymnastics movements do not come only through comprehensive and extensive study, which is through specialized research in everything related to this sport with the aim of raising the technical level of players on the one hand and developing aerobic gymnastics on the one hand. (10:11)

Muhammad Ibrahim, Ahmed Al-Shazly (2006) and Talha Husam Al-Din (1993) agree that the ideal movement represents one of the dynamic patterns of technical tracks that are concerned with the highest level of training performance of players, which depend on some criteria that is associated with many of the coach's technical capabilities and data available for the players, whereas the competition has shown the significance of studying the skills components with a more detailed approach in order to identify its accurate features, in addition to the establishment of the appropriate development approaches for the purpose of reaching ideal performance.

(13: 66) (8: 405)

Dong Xin-jun, Diao Zai zhen (2005), Elfi, and Claire (2007) also agree that the sport of aerobic gymnastics is among the most significant and effective sports, which requires advance methods and approaches for training, so it would cope with the changes to develop the players' performance level. (1:23) (24:94)

Both researchers agree upon what was referred by Mohamed Gaber and Khairiah Al Sokary (2010) that the performances, which are characterized with high speed must be captured in video, so each position taken by the torso or the muscle used in performance can be analyzed as stages and also hold comparison between the distinctive high level performances foe world champions, which can be obtained from the federations concerned with aerobic gymnastics. (15:85)

Each of GREGORY, KEVIN, and FORD (2005) mentions that the use of biomechanical analysis is the scientific approach to develop the training and performance program, whereas it works on improving the performance and correcting the errors, as well as the development of technical performance and physical fitness training program for the female and male players, as it also prevents injuries. (25:25)

Owais al-Jabali (2000 AD) and Muhammad Bureka 'and the Khairiah Al Sokary (2011) agree that using analytical methods can reach the accurate details of movement and identify the form of performance and master its details in a manner that achieves effort saving. (11:65) (16:131)

The lift skill is deemed among the modern aerobic gymnastics skills on the apparatus of ground movements with (G) difficulty, whereas as it increases upon the payer's performance of the whole movement to raising the value of difficulty of the whole movement. (22:32)

The researchers noticed the decrease and weakness of the results of the Egyptian players at the international and global level as a result of their inability to develop their performance with skills with "G" difficulty since the application of these difficulties in 2017 in the world championships and in the light of the researchers' views of 
many international and global tournaments, they managed to show the widespread use of world class players for the skill of (lift) and that it has an impact on the referees' assessment on performance, whereas the Egyptian players could not perform it until the time of the researchers' attempt to conduct their studies, which was a motive for conducting a biomechanical analysis therefor, so that we can reach to keep pace with global levels.

The two researchers have reviewed the sources of scientific references regarding the description of this advance skill or the extent of availability of exercises, which demonstrates the difficulty of executing this advance skill and particularly for the Egyptian players on the basis of being modern skills and mostly the Egyptian players did not possess the references that help them in understanding the technical performance methods, in addition to the unavailability of certain models of the performance exercises related to this kind of skills and what is being carried out currently is nothing but personal efforts on the trainers' part.

Therefore, the two researchers saw that it is necessary to establish directed exercises on scientific basis with biomechanical indicators connotations in accordance with sound scientific basis and clear and specified objectives in light of analyzing the distinctive biomechanical features of the Italian team, which is the world number one team in terms of lifting skill performance's classification for aerobic dance gymnastics.

Whereas the establishment of a set of exercises for skills with high difficulty in light of biomechanical features distinguishing them is a decisive factor to master and acquire the skills, also the gymnast can control her body shape when making the spin, whereas that contributes in flying time and establishment of exercises for each of the performance stages (approach - jump - flying and spinning - landing - steadiness), which contributes in developing the skillful performance of lift skill for players of Egyptian national gymnastics team, whereas this research is deemed the first research in the field of aerobic dance gymnastics through the establishment of directed exercises in light of biomechanical features distinguishing the lift skill within the limits of the two researchers knowledge, as well as the research sample, which is the first team recommended to represent Egypt in international tournaments

\section{- Research Significance: \\ - Scientific Significance:}

Attempting to provide the workers in the field of aerobic gymnastics training with some knowledge and information about components and details of performance of the lifting skill of aerobic dance gymnasts through the identification of the distinctive biomechanical characteristics of study skill.

\section{- Application Significance:}

The application significance returns to the possibility of using what is concluded from the result to raise the level of skillful performance for (lift) skill for aerobic dance gymnasts through learning and training program.

\section{- Research Goals:}

1- Biochemical characterization of lift skill in aerobic dance gymnasts.

2- Determination of the quantitative values of some biochemical variables of the lift skill for aerobic dance gymnasts.

3- Designing a training program using guided exercises in the light of (kinematic analysis) of the lift skill for aerobic dance gymnasts.

4- Identifying the impact of the training program on the physical and skill variables subject matter of research.

\section{Research Questions:}

1- What is the biochemical characterization of lift skill in aerobic dance gymnasts?

2- What are the quantitative values of some biochemical variables of the lift skill of aerobic dance gymnasts?

3- What is the effect of the training program on the physical and skill variables subject matter of research?

\section{- Terminology used in research: \\ - Targeted Training:}


They are sport movements that are similar in composition to kinetic performance in competition in terms of strength, speed, and kinetic course as well as in the direction of muscle work. (4)

\section{- Kinematic analysis:}

It is a descriptive science that describes movement in an abstract description without being exposed to the forces causing it. (16: 70$)$

\section{- Lift Skill:}

It is one of $(G)$ difficulty skills in aerobic gymnastics that require raising above the shoulder level around the crossaxis of the body and performing the skill without stopping and requiring strength in performance. (22:29)

\section{- Research Procedure:}

First: Research Methodology: The two researchers used the descriptive method (case study)

The experimental method using single group and the two measurements (prior - post).

Second: Research Sample (skill): lift skill for Italy aerobic dance gymnastic team in world champion 2017, which came in first place.

Human Research Sample: the sample was selected with the intentional method for number of 8 aerobic gymnasts, who are registered in Egyptian Gymnastics Federation.

Table (1)

Homogeneity of the research sample in the variables (age - weight - height - training age) $\mathbf{N}=(8)$ players

\begin{tabular}{c|c|c|c|c|c|c}
\hline \hline No. & Variables & $\begin{array}{c}\text { Measurement } \\
\text { units }\end{array}$ & Average & Mediator & $\begin{array}{c}\text { Standard } \\
\text { deviation }\end{array}$ & $\begin{array}{c}\text { Sprain } \\
\text { Coefficient }\end{array}$ \\
\hline \hline 1 & Age & Year & $\mathbf{1 8 . 2 4}$ & $\mathbf{1 6 . 0 0}$ & .704 & $\mathbf{. 5 3 7}$ \\
\hline 2 & Length & Meter & $\mathbf{1 5 8 . 1 2}$ & $\mathbf{1 7 0 . 0}$ & $\mathbf{4 . 7 4}$ & $\mathbf{- . 1 9 6}$ \\
\hline 3 & Weight & K.G & $\mathbf{5 7 . 3 7}$ & $\mathbf{6 1 . 5 0}$ & $\mathbf{4 . 0 2}$ & $\mathbf{. 0 1 8}$ \\
\hline 4 & $\begin{array}{c}\text { Training } \\
\text { age }\end{array}$ & Year & $\mathbf{3 . 7 0}$ & $\mathbf{3 . 0 0}$ & 1.31 & .036 \\
\hline \hline
\end{tabular}

It is indicated from Table (1) that the values of sprain coefficients in the variables of (age - length - weight - training age) have been limited between $( \pm 3)$, which indicates the moderate distribution of the sample, and the homogeneity of the research sample in these variables.

Third: Means of Data Collection: The International Gymnastics Federation http://www.fig.com was relied upon and the skill was obtained from the Federation website, whereas the camera speed was read on the analysis program and its speed reached 25 image per second, where (the cadre time 0.04 second). This film is valid for analysis through:

- Camera stability: one of the points was placed on the screen on a certain part inside the film and was film was played from the movement start until its end, it was revealed that the point position was not changed, which proved to the researchers that the camera is in a stable status during the filming process, which is one of the followed condition to conduct filming process "camera stability."

- - The motion analysis program: "3D Map" Motion analysis program, registered at the Center for Information Systems at the Academy of Scientific Research under No. 665/5, date of 05/23/2001, Mostafa Atwa. 
Fourth: Tests used in research:

1 Shuttle running for the distance of $54 \mathrm{~m}$

Second

( $18: 228)$

$2 \quad$ Fixed balance measurement

Second

$(10: 571)$

3 Bending the torso in front below from standing

Meter

$(18: 265)$

$4 \quad$ Wide jump from stable position

Meter

$(12: 80)$

$5 \quad$ Sitting from running for 30 seconds

No.

$6 \quad$ Hanging

Second

7 Shuttle running for the distance of $9 \mathrm{~m}$

Second

8 Diagonal face down from standing position

No.

9 Running $30 \mathrm{~m}$ from slow start

Second

$(1: 108)$

$10 \quad$ Lift skill

Degree

Used devices and tools:

1- An electronic scale.

2- Restameter.

3- A tape measure to measure distances.

4- Stopwatch.

5- Mat.

6- Video camera.

7- Computer.

8- Kinovea.

9- Weight training gym contains (weight training devices).

Table (2)

Homogeneity of the research sample in measurements of physical fitness and lift skill subject matter of research, $\mathbf{N}=(8)$ players

\begin{tabular}{c|c|c|c|c|c|c}
\hline \hline No. & Variables & $\begin{array}{c}\text { Measurement } \\
\text { units }\end{array}$ & Average & Mediator & $\begin{array}{c}\text { Standard } \\
\text { deviation }\end{array}$ & $\begin{array}{c}\text { Sprain } \\
\text { Coefficient }\end{array}$ \\
\hline \hline 1 & $\begin{array}{c}\text { Shuttle running for the distance } \\
\text { of 54 } m\end{array}$ & Second & 19.91 & 19.00 & 10.82 & -.991 \\
\hline 2 & Fixed balance measurement & Second & 8.98 & 8.39 & 1.04 & 1.41 \\
\hline 3 & $\begin{array}{c}\text { Bending the torso in front below } \\
\text { from standing }\end{array}$ & Meter & 11.75 & 11.50 & 1.93 & -.439 \\
\hline 4 & Wide jump from stable position & Meter & 1.64 & 1.00 & 3.18 & .177 \\
\hline 5 & $\begin{array}{c}\text { Sitting from running for 30 } \\
\text { seconds }\end{array}$ & No. & 15.62 & 15.00 & 11.32 & -.073 \\
\hline 6 & Hanging & Second & 7.91 & 7.00 & 10.521 & -.178 \\
\hline 7 & $\begin{array}{c}\text { Shuttle running for the distance } \\
\text { of 9 } m\end{array}$ & Second & 6.72 & 6.50 & 17.34 & .415 \\
\hline 8 & $\begin{array}{c}\text { Diagonal face down from } \\
\text { standing position }\end{array}$ & number & 13.75 & 13.50 & 21.66 & -.096 \\
\hline 9 & Running 30 m from slow start & Second & 6.24 & 6.00 & .83 & -.277 \\
\hline 10 & Total level & Degree & 0.5 & 0.49 & .94 & -.138 \\
\hline \hline
\end{tabular}


It is indicated from Table (2) that the values of sprain coefficients in the variables of physical level and lift skill have been limited between $( \pm 3)$, which indicates the moderate distribution of the sample, and the homogeneity of the research sample in these variables.

Validity of the tests (validation of differentiation): Stability coefficient:

Table (3)

Differences indication with Man Whitney Test for survey sample group (distinguished - nondistinguished) in the tests of skill and physical variables for aerobic dance gymnasts subject matter of research $-\mathbf{N} 1=\mathbf{N} 2=8$ players

\begin{tabular}{|c|c|c|c|c|c|c|c|c|c|}
\hline No. & Tests & $\begin{array}{l}\text { Measurement } \\
\text { unit }\end{array}$ & Group & No. & $\begin{array}{c}\text { Rank } \\
\text { average }\end{array}$ & Rank total & $\begin{array}{l}\text { Value } \\
\text { of "y" }\end{array}$ & $\begin{array}{l}\text { Correlation } \\
\text { coefficient }\end{array}$ & $\begin{array}{l}\text { Possibility } \\
\text { of error }\end{array}$ \\
\hline \multirow{2}{*}{1} & \multirow{2}{*}{$\begin{array}{l}\text { Shuttle running } \\
\text { for the distance } \\
\text { of } 54 \mathrm{~m}\end{array}$} & \multirow{2}{*}{ Second } & $\begin{array}{c}\text { non- } \\
\text { distinguished }\end{array}$ & 8 & 4.50 & 36.00 & \multirow{2}{*}{3.388} & \multirow{2}{*}{$.975^{* *}$} & \multirow{2}{*}{001} \\
\hline & & & distinguished & 8 & 12.50 & 100.00 & & & \\
\hline \multirow{2}{*}{2} & \multirow{2}{*}{$\begin{array}{l}\text { Fixed balance } \\
\text { measurement }\end{array}$} & \multirow{2}{*}{ Second } & $\begin{array}{c}\text { non- } \\
\text { distinguished } \\
\end{array}$ & 8 & 4.50 & 36.00 & \multirow{2}{*}{3.391} & \multirow[t]{2}{*}{$.853^{* *}$} & \multirow[t]{2}{*}{001} \\
\hline & & & distinguished & 8 & 12.50 & 100.00 & & & \\
\hline \multirow[b]{2}{*}{3} & \multirow{2}{*}{$\begin{array}{l}\text { Bending the } \\
\text { torso in front } \\
\text { below from } \\
\text { standing }\end{array}$} & \multirow[b]{2}{*}{ Meter } & $\begin{array}{c}\text { non- } \\
\text { distinguished }\end{array}$ & 8 & 4.56 & 36.50 & \multirow[b]{2}{*}{3.368} & \multirow[b]{2}{*}{$.999^{* *}$} & \multirow{2}{*}{001} \\
\hline & & & distinguished & 8 & 12.44 & 99.50 & & & \\
\hline \multirow{2}{*}{4} & \multirow{2}{*}{$\begin{array}{l}\text { Wide jump } \\
\text { from stable } \\
\text { position }\end{array}$} & \multirow{2}{*}{ Meter } & $\begin{array}{c}\text { non- } \\
\text { distinguished } \\
\end{array}$ & 8 & 4.50 & 36.00 & \multirow{2}{*}{3.414} & \multirow{2}{*}{$.824^{*}$} & \multirow[t]{2}{*}{001} \\
\hline & & & distinguished & 8 & 12.50 & 100.00 & & & \\
\hline \multirow{2}{*}{5} & \multirow{2}{*}{$\begin{array}{l}\text { Sitting from } \\
\text { running for } 30 \\
\text { seconds }\end{array}$} & \multirow{2}{*}{ number } & $\begin{array}{c}\text { non- } \\
\text { distinguished }\end{array}$ & 8 & 4.50 & 36.00 & \multirow{2}{*}{3.368} & \multirow{2}{*}{$.740^{*}$} & \multirow{2}{*}{001} \\
\hline & & & distinguished & 8 & 12.50 & 100.00 & & & \\
\hline \multirow{2}{*}{6} & \multirow{2}{*}{ Hanging } & \multirow{2}{*}{ Second } & $\begin{array}{c}\text { non- } \\
\text { distinguished } \\
\end{array}$ & 8 & 4.50 & 36.00 & \multirow{2}{*}{3.957} & $.982^{* *}$ & 006 \\
\hline & & & distinguished & 8 & 12.50 & 100.00 & & & \\
\hline 7 & $\begin{array}{l}\text { Shuttle running } \\
\text { for the distance }\end{array}$ & Second & $\begin{array}{c}\text { non- } \\
\text { distinguished } \\
\end{array}$ & 8 & 4.75 & 38.00 & 3.313 & $.977^{* *}$ & 001 \\
\hline & of $9 \mathrm{~m}$ & & distinguished & 8 & 12.25 & 98.00 & & & \\
\hline & $\begin{array}{l}\text { Diagonal face } \\
\text { down from }\end{array}$ & & $\begin{array}{c}\text { non- } \\
\text { distinguished } \\
\end{array}$ & 8 & 4.50 & 36.00 & & & \\
\hline 8 & $\begin{array}{l}\text { standing } \\
\text { position }\end{array}$ & number & distinguished & 8 & 12.50 & 100.00 & 2.427 & $.993^{* *}$ & 004 \\
\hline 9 & Running $30 \mathrm{~m}$ & Second & $\begin{array}{c}\text { non- } \\
\text { distinguished }\end{array}$ & 8 & 12.50 & 100.00 & 3.172 & $953^{* *}$ & 001 \\
\hline & slow start & & distinguished & 8 & 4.50 & 36.00 & & & \\
\hline 10 & Total level & Degree & $\begin{array}{c}\text { non- } \\
\text { distinguished }\end{array}$ & 8 & 4.50 & 36.00 & 2.253 & $.925^{* *}$ & 004 \\
\hline & & & distinguished & 8 & 12.50 & 100.00 & & & \\
\hline
\end{tabular}

* The tabular value of the "y" at the moral level $(0.05)=1.96$

* The tabular value of the "R" at the moral level $(0,05)=(0666)$

From the table 0 , it is indicated that there are statistically significant differences between the two groups of the exploratory sample (distinctive - non-distinctive) in the tests of physical and skill variables for gymnasts under subject matter of research, whereas the calculated value of " $y$ " was greater than the table value of " $y$ " at moral level of $(0,05)$, which indicates the validity of the tests subject matter of research and presence of a statistically significant correlation at the moral level of (0.05) between the two applications (first - second) of the study sample. 
- Training Program (enclosure 5).

Table (4)

\begin{tabular}{|c|c|c|}
\hline No & Program's main objective & $\begin{array}{l}\text { - Raising the physical performance level for aerobic dance } \\
\text { gymnasts. } \\
\text { Raising the skill performance level (lift) for aerobic dance } \\
\text { gymnastics. }\end{array}$ \\
\hline 1 & $\begin{array}{l}\text { Planning the training } \\
\text { program. }\end{array}$ & $\begin{array}{l}\text { Targeted training program in direction of motor course for } \\
\text { the skill subject matter of the research, which is resulted from } \\
\text { Kinematic analysis. Enclosure (9) }\end{array}$ \\
\hline 2 & Program execution period & $\begin{array}{l}\text { (12 weeks) foundation stage ( } 4 \text { weeks) - preparation stage (4) } \\
\text { weeks - pre-competition stage (4) weeks. }\end{array}$ \\
\hline 3 & Number of week units & (4 units) Saturday, Monday, Wednesday, and Friday. \\
\hline 4 & Execution period & Special preparation and pre-competitions. \\
\hline 5 & Units number & (48 unit) \\
\hline 6 & Unit time & 120 min. \\
\hline 7 & Program total time & (5760 min), which is (96 hours) \\
\hline 8 & Used training methods & $\begin{array}{l}\text { (Periodic training with low intensity - periodic training with high } \\
\text { intensity - repetitive training). }\end{array}$ \\
\hline 9 & Forming training load & Ripple method $(1-3)(1-2)$ \\
\hline
\end{tabular}

- Rationing the intensity of training loads within the targeted training program

Table (5)

Determining the repetitions in accordance with the maximum weight that can be lifted once

\begin{tabular}{|c|c|c|c|c|}
\hline Load degree & Intensity & Repetition & Set & Rest between sets \\
\hline \multirow{2}{*}{ Maximum } & $100 \%$ & 1 & 1 & \multirow{2}{*}{$1.50-3 \mathrm{~min}$} \\
\hline & $95 \%$ & 2 & $1-3$ & \\
\hline \multirow{4}{*}{ Less than maximum } & $93 \%$ & 3 & $1-3$ & \multirow{4}{*}{$3-4 \mathrm{~min}$} \\
\hline & $90 \%$ & 4 & $1-3$ & \\
\hline & $87 \%$ & 5 & $3-4$ & \\
\hline & $85 \%$ & 6 & $3-4$ & \\
\hline \multirow{4}{*}{ Height } & $83 \%$ & 7 & $3-4$ & \multirow{4}{*}{$3-5 \mathrm{~min}$} \\
\hline & $80 \%$ & 8 & $3-4$ & \\
\hline & $77 \%$ & 9 & $3-5$ & \\
\hline & $75 \%$ & 10 & $3-5$ & \\
\hline \multirow{2}{*}{ Average } & $67 \%$ & 12 & $3-5$ & \multirow{2}{*}{$1.50-3 \mathrm{~min}$} \\
\hline & $65 \%$ & 15 & $3-5$ & \\
\hline
\end{tabular}


Estimate the volume of skill repetitions in aerobic dance gymnastics according to energy production systems.

Table (6)

\begin{tabular}{c|c|c|c}
\hline \hline \multirow{3}{*}{$\begin{array}{c}\text { Performance time } \\
\text { by second }\end{array}$} & Competitions & $\% 15$ & $\% 5$ \\
\cline { 2 - 4 } & Anaerobic & Special & General \\
\cline { 2 - 4 } & 10 sec. & 30 sec. & Aerobics \\
\hline \hline 2 sec. & 5 & 15 & 180 sec. \\
\hline 2.1 sec. & 5 & 15 & 90 \\
\hline 2.2 sec. & 5 & 14 & 86 \\
\hline 2.3 sec. & 4 & 13 & 78 \\
\hline 2.4 sec. & 4 & 12 & 75 \\
\hline 2.5 sec. & 4 & 12 & 72 \\
\hline 2.6 sec. & 3 & 11 & 68 \\
\hline 2.7 sec. & 3 & 11 & 65 \\
\hline \hline
\end{tabular}

- Time schedule.

- Model Analysis and Extraction of Kinematic Variables (Horizontal and Vertical Distance - Collected Speed) 5/4/2019 enclosure (1).

- Determination of targeted trainings in the light of biochemical analysis 20/4/2019 enclosure (4).

- Prior measurements: The physical and skill prior measurements were carried out for the individuals in the research sample from the day 5/5/5/2019 enclosure (6)

- Determination of maximum weight: 11 days, 12/5/2019.

- Execution of the program: The proposed program was executed from 5/15/2019 to 8/15/2019 enclosure (5).

- Post measurements: The post measurements were carried out on 16/8 until 8/8/2019, with the same conditions and specifications of prior measurement and the same place as well. 


\section{- Results presentation and discussion.}

\section{Biochemical description of lift skill in aerobic dance gymnasts}

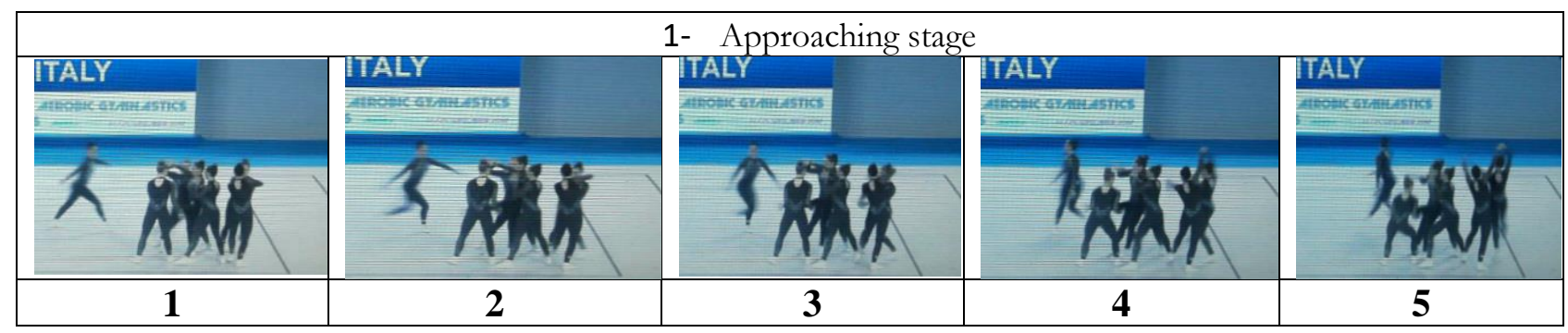

The approach goes through three parts to perform the motor shifting from running, whereas it is represented in the pictures from (1-5), starts with approaching the start point, then running on insteps first step with right leg as wide approaching step in the horizontal direction, besides body inclination in the movement direction, stabbing on the right leg and spinning towards the right direction of right arm therein, in addition to extra extension behind the body, the left arm bend in front of the chest and moving both arms to the left in opposition to leg movement. Second step, pushing with the back foot in order to make a long step to gain an amount of transition speed, the hip in ninety-degree angle with the leg, horizontal extension for both arms on the shoulders level, spinning the torso to the front and looking straight forward. Side step, directing the body with quarter spin inside in order to take a short side step that enables him of proper preparation of jumping process and during running the leg moves and quickly placed down and behind closely from the line of body mass weight, whereas it shall be taken into account upon frontal pivot with foot, not to bend the kneecap too hard in order to avoid extra load on the working muscles, while the leg extends in the back pivot stage at the time of lifting the hip of the free leg with the angle of approximately (55 - 65), as the leg shall be pushed, while fully extended and the foot joint during maximum bending. The arms shall be bended in half and the tows shall be in semi-bending position and the play shall look straight forward. The torso shall slightly incline forward in the approach, which would help on increasing the approach speed, because it contributes in pushing the body forwards due to fall of body gravity center in front of the leg touching the ground, whereas the angle of torso inclination forward differs from a player to another according to its length, which is approximately (80) degree in the last stage of approach, in which the player reaches her maximum speed or the closest to it.

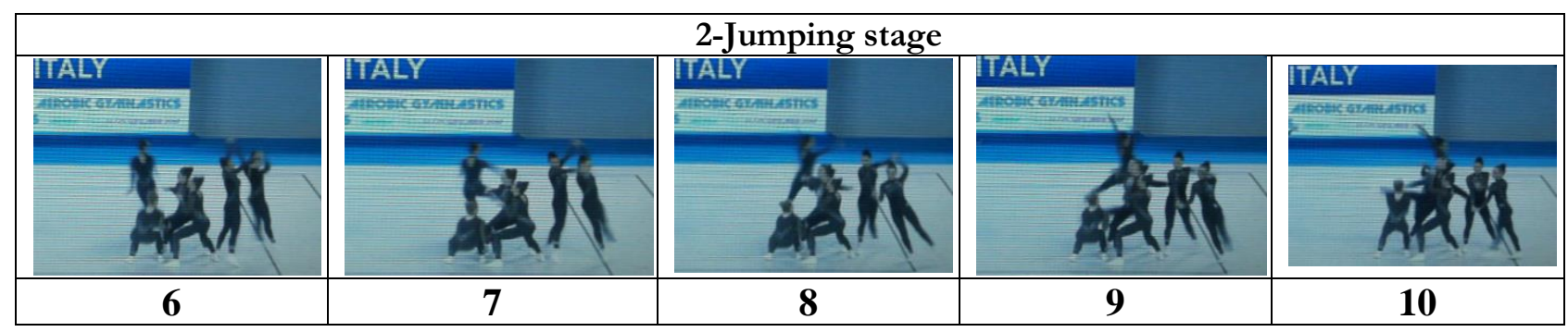

It is represented in the pictures from (6-10) double jumping in position of front hip in synchronization with swinging the arm up to lifting the body higher at the time of release with the continuance of torso stability, while taking in to account that the continuance of keeping both arms up during raising until the shoulders level during the process of the body lift on flying course for the purpose of increasing inertia torque for the body around the vertical axis. As the horizontal speed, which is the speed resulted from approach, as for vertical speed, it results from pushing, whereas both of these speeds result pushing with foot and both hands are moved upon performing from the back position down and to the front, while in the moment of the players touching, the concentration shall be high, because failure leads to falling. 


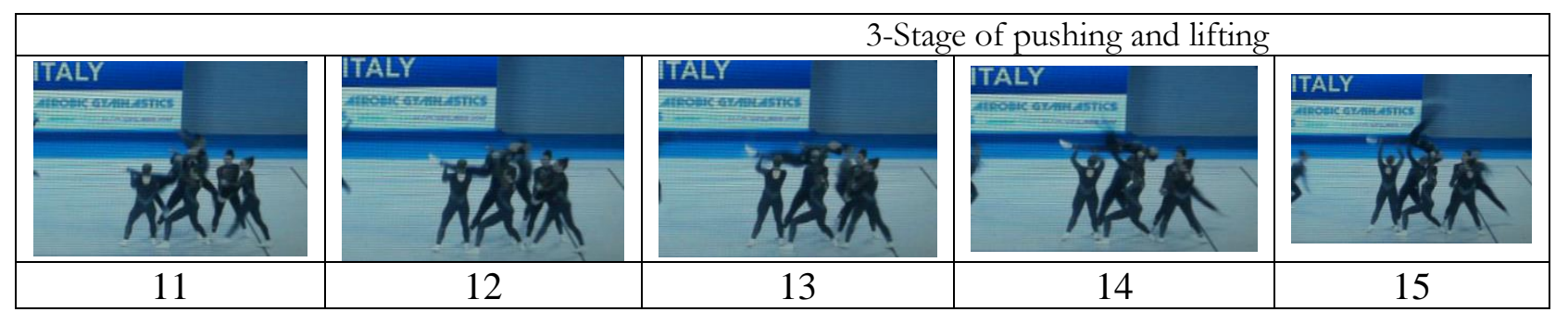

It is represented in the pictures from (11 - 15), whereas the players carry the player from the running position on the back with forearms and the body on full extension and holding the forearms with the extension of insteps and feet joint, which give her a chance in increasing the force outcome at the moment of pushing, and the feet position shall be on the pushing point, as the player bends both kneecaps at the moment of pushing with high degree and that results upon the occurrence of counter action, which is pushing, whereas the correct swinging of both arms and pushing the player from forearms greatly helps on lift of body flying curve and the proper compatibility in the process of working muscles sets helps in producing the required force. The Pushing is performed from both forearms to the full extension of the body during lifting high, which helps in increasing the movement speed up and lifting in opposite direction to the body, which means pushing the player up and the body shape shall be raised to the shoulders level and the body continues its movement due to Inertia, so the body moves up. The lift shall be made in a regular and gradual manner, in addition to continuance for the gained speed from the previous staged and that to increase the lift higher.

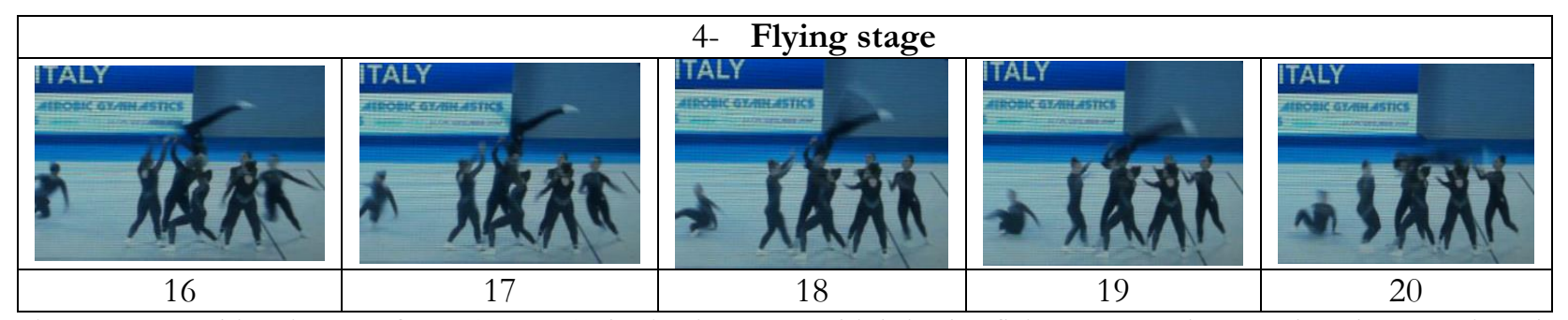

It is represented in pictures from (16 - 20) the basic stage, which is the flying stage, whereas the player makes the back wheel on both shoulders from leaning on the players and it is indicated from picture (16), the hip is opened with approximately 180-degree angle and the torso on full extension, after the process of pushing and lifting the forearms strongly up, in order to lift the body higher and the player continues in this stage until high extension. This stage helps the player in terms of the legs, which works on increasing the body spinning in a correct form around the vertical axis, whereas it is higher than the shoulders level and in clear form, as the player flats out, which directly impacts the players scores and the player maintains her body in the correct position, which is a straight and nearly flat position under the effect of gravity.

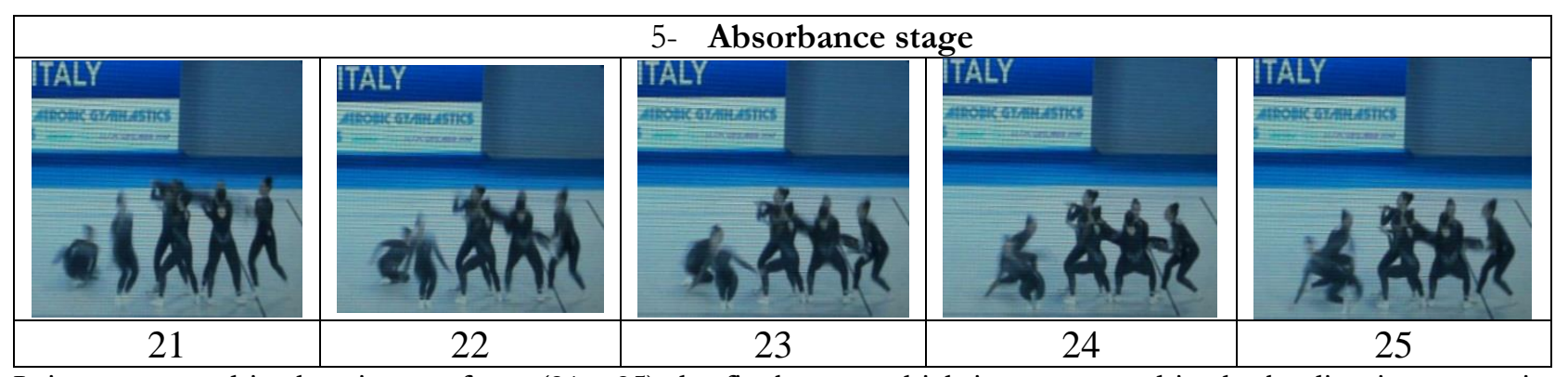

It is represented in the pictures from (21 - 25) the final stage, which is represented in the landing in prostration position, whereas the players absorb the player, until the two assisting players meet the player feet in proper form by bending the keens of all players, who are five players and the absorbance shall be inclined form for one of the players at the head and two others carry the torso and the final two at both hips and knee in corresponding form. Movement absorbance enables us to complete the motor duty successfully and enables the player to each balance status quickly. 
Presenting and discussing the results of time distribution of lift skill for aerobic dance gymnasts.

Table (7)

Time distribution of lift skill for aerobic dance gymnasts

\begin{tabular}{c|c|c|c|c|c}
\hline \hline No. & Stage & From : To & Pictures & $\begin{array}{c}\text { Time } \\
(\text { Sec.) }\end{array}$ & $\begin{array}{c}\text { Contribution } \\
\text { percentage }\end{array}$ \\
\hline \hline 1 & Approaching & $(1-5)$ & 5 & 0.4 & $14.81 \%$ \\
\hline 2 & Jumping & $(6-10)$ & 5 & 0.5 & $18.52 \%$ \\
\hline 3 & Pushing and lifting & $(11-15)$ & 5 & 0.5 & $18.52 \%$ \\
\hline 4 & Flying & $(16-20)$ & 5 & 0.5 & $18.52 \%$ \\
\hline 5 & Landing & $(21-27)$ & 7 & 0.7 & $25.92 \%$ \\
\hline
\end{tabular}

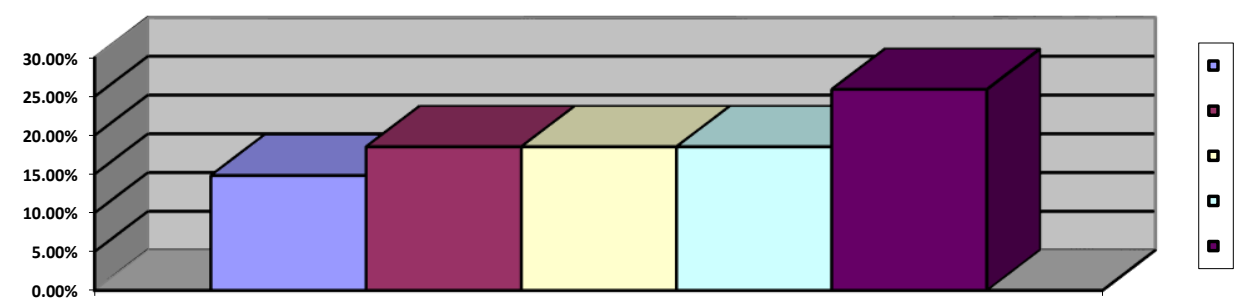

Shape (1) percentages of time distribution for technical stages of lift skill for aerobic dance gymnasts

It is indicated from table (7) that the skill of (lift) for world class aerobic dance gymnasts has taken a time period that reached $(2,6)$ second and the movement was divided into five stages represented in (approaching) and it took $(0,4)$ second, whereas the time of the first picture equals zero, while the jumping stage took $(0,5$ second), as the stage of pushing and lifting took ( 0,5 second), also flying stage took $(0,5$ second), while the landing has taken $(0,7$ second), each stage of the movement has contributed with a percentage that reached in stage of approaching, jumping, pushing, lifting, and flying $18,5 \%$, while the contribution percentage of landing reached $26 \%$. 


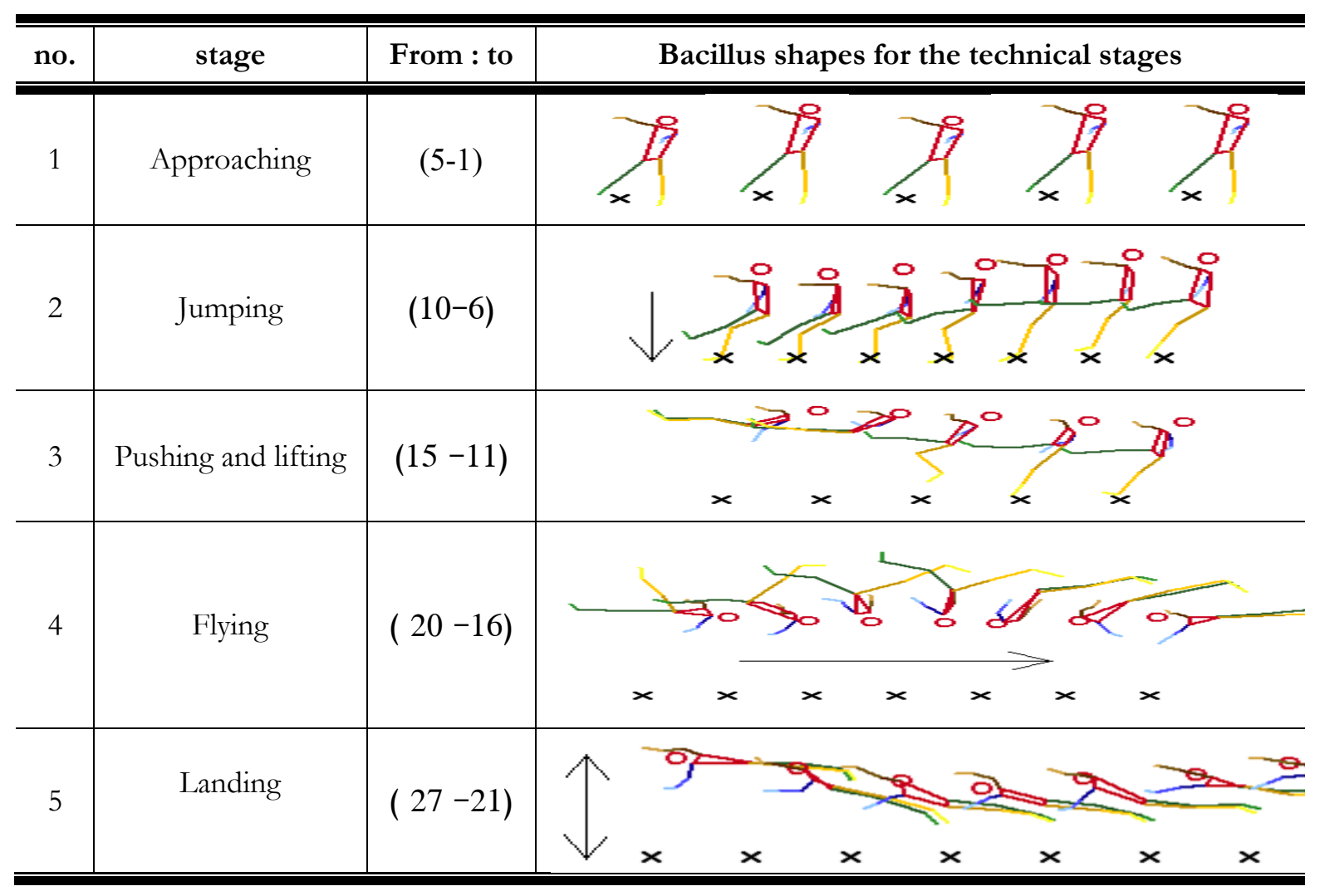


Presenting and discussing the results of horizontal and vertical distance (body gravity center - right foot - left foot - head) of lift skill aerobic dance gymnasts.

Table (8)

Horizontal and vertical distance (body gravity center - right foot - left foot - head) of lift skill aerobic dance gymnasts

\begin{tabular}{|c|c|c|c|c|c|c|c|c|c|}
\hline \multirow[t]{2}{*}{ Pictures } & \multirow[t]{2}{*}{ Time } & \multicolumn{2}{|c|}{$\begin{array}{c}\text { C / body } \\
\text { gravity }\end{array}$} & \multicolumn{2}{|c|}{ C / right foot } & \multicolumn{2}{|c|}{ C / left foot } & \multicolumn{2}{|c|}{ C / head } \\
\hline & & $\mathbf{x}$ & $\mathbf{y}$ & $\mathbf{X}$ & $\mathbf{Y}$ & $\mathbf{X}$ & $\mathbf{Y}$ & $\mathbf{X}$ & $\mathbf{Y}$ \\
\hline 1 & $\mathbf{0}$ & 0.308 & 0.976 & -0.116 & 0.232 & $\mathbf{0 . 3 9 7}$ & 0.066 & 0.43 & 1.639 \\
\hline 2 & 0.1 & 0.245 & 1.102 & -0.298 & 0.828 & -0.017 & 0.281 & 0.414 & 1.721 \\
\hline 3 & 0.2 & 0.24 & 1.146 & $\begin{array}{l}-0.43 \\
\end{array}$ & 0.943 & 0.017 & 0.199 & 0.381 & 1.771 \\
\hline 4 & 0.3 & 0.205 & 1.093 & -0.348 & 0.91 & 0.017 & 0.099 & 0.364 & 1.705 \\
\hline 5 & 0.4 & 0.204 & 0.956 & $-\mathbf{- 0 . 3 3 1}$ & 0.612 & $\mathbf{0 . 0 8 3}$ & 0 & 0.381 & 1.605 \\
\hline 6 & 0.5 & \begin{tabular}{|l|l|}
0.235 \\
\end{tabular} & 0.861 & -0.348 & 0.414 & 0.066 & 0.033 & 0.314 & 1.523 \\
\hline 7 & 0.6 & 0.259 & 0.855 & -0.265 & 0.232 & 0.033 & 0 & 0.298 & 1.456 \\
\hline 8 & 0.7 & 0.25 & 0.9 & -0.281 & 0.348 & -0.017 & 0.017 & 0.348 & 1.539 \\
\hline 9 & 0.8 & 0.283 & 1.139 & \begin{tabular}{|c|}
-0.43 \\
\end{tabular} & 1.026 & -0.017 & 0.116 & 0.579 & 1.688 \\
\hline 10 & 0.9 & \begin{tabular}{|c|c|}
0.304 \\
\end{tabular} & 1.247 & -0.414 & 1.192 & $\mathbf{0 . 0 1 7}$ & 0.348 & 0.629 & 1.721 \\
\hline 11 & 1 & 0.268 & 1.377 & -0.414 & 1.357 & 0.199 & 0.579 & 0.645 & 1.821 \\
\hline 12 & 1.1 & 0.287 & 1.633 & -0.596 & 1.589 & -0.48 & 1.622 & 0.712 & 1.887 \\
\hline 13 & 1.2 & \begin{tabular}{|c|}
0.318 \\
\end{tabular} & 1.728 & $\begin{array}{l}-0.497 \\
\end{array}$ & 1.788 & -0.48 & 1.738 & 0.877 & 1.936 \\
\hline 14 & 1.3 & 0.36 & 1.962 & -0.579 & 1.97 & 0 & 2.665 & 0.778 & 1.771 \\
\hline 15 & 1.4 & 0.4 & 2.034 & -0.497 & 2.102 & 0.662 & 2.963 & 0.728 & 1.705 \\
\hline 16 & 1.5 & 0.443 & 2.214 & $-\mathbf{- 0 . 3 3 1}$ & 2.764 & 1.192 & 2.979 & 0.546 & 1.672 \\
\hline 17 & 1.6 & 0.496 & 2.279 & -0.132 & 3.062 & 1.225 & 2.863 & 0.447 & 1.655 \\
\hline 18 & 1.7 & 0.58 & 2.123 & 1.407 & 2.698 & 1.357 & 2.714 & 0.166 & 1.639 \\
\hline 19 & 1.8 & 0.579 & 2.022 & 1.473 & 2.582 & 1.423 & 2.632 & 0.132 & 1.688 \\
\hline 20 & 1.9 & 0.642 & 1.763 & 1.539 & 1.986 & 1.523 & 1.837 & 0.083 & 1.771 \\
\hline 21 & 2 & 0.844 & 1.536 & 1.705 & 1.44 & 1.754 & 1.407 & 0.232 & 1.605 \\
\hline 22 & 2.1 & 0.764 & 1.16 & 1.556 & 0.728 & 1.622 & 0.761 & 0.43 & 1.44 \\
\hline 23 & 2.2 & 0.834 & 0.955 & 1.705 & 0.695 & 1.605 & 0.712 & 0.463 & 1.241 \\
\hline 24 & 2.3 & 0.822 & 0.934 & 1.705 & 0.695 & 1.605 & 0.712 & 0.298 & 1.125 \\
\hline 25 & 2.4 & 0.827 & 0.985 & 1.705 & 0.877 & 1.672 & 0.828 & 0.314 & 1.291 \\
\hline 26 & 2.5 & 0.819 & 1.175 & 1.655 & 1.076 & 1.672 & 1.109 & 0.43 & 1.341 \\
\hline 27 & 2.6 & 0.774 & 1.397 & 1.605 & 1.258 & 1.589 & 1.258 & 0.364 & 1.539 \\
\hline
\end{tabular}

It is indicated from table (8) that the horizontal distance for body gravity center during the performance of the approaching stage has reached $(0,30)$ meter, while the maximum vertical height has reached $(1,14)$ meter and the minimum position $(0,95)$ meter. As the horizontal distance for the body gravity center during the performance of jumping stage has reached $(0,30)$ meter, while the maximum vertical height has reached $(1,24)$ meter and minimum position $(0,85)$ meter. Whereas the horizontal distance for body gravity center during the performance of the stage of pushing and lifting has reached $(0,40)$ meter, while the maximum vertical height has reached $(2,03)$ meter and the minimum position $(1,37)$. The horizontal distance for body gravity center during the performance of the flying stage has reached $(0,64)$ meter, while the maximum vertical height has reached $(2,28)$ meter and the minimum position $(1,76)$. The horizontal distance for body gravity center during the performance of the landing stage has reached $(0,84)$ meter, while the maximum vertical height has reached $(1,53)$ meter and the minimum position $(0,93)$. 
It is indicated from table (8) that the horizontal distance for right foot instep during the performance of approaching stage has reached $(0,11)$ meter, while the maximum vertical height has reached $(0,94)$ meter and minimum position $(0,23)$ meter. The horizontal distance for right foot instep during the performance of jumping stage has reached $(0,26-)$ meter, while the maximum vertical height has reached $(1,19)$ meter and minimum position $(0,23)$ meter. The horizontal distance for right foot instep during the performance of pushing and lifting stage has reached $(0,41-)$ meter, while the maximum vertical height has reached $(2,10)$ meter and minimum position $(1,36)$ meter. The horizontal distance for right foot instep during the performance of flying stage has reached $(1,54-)$ meter, while the maximum vertical height has reached $(3,06)$ meter and minimum position $(1,99)$ meter. The horizontal distance for right foot instep during the performance of landing stage has reached (1,71-) meter, while the maximum vertical height has reached $(1,08)$ meter and minimum position $(0,69)$ meter.

It is indicated from table (8) that the horizontal distance for left foot instep during the performance of approaching stage has reached $(0,39)$ meter, while the maximum vertical height has reached $(0,28)$ meter and minimum position $(0,07)$ meter. The horizontal distance for left foot instep during the performance of jumping stage has reached $(0,07)$ meter, while the maximum vertical height has reached $(0,35)$ meter and minimum position $(0,02)$ meter. The horizontal distance for left foot instep during the performance of pushing and lifting stage has reached $(1,99)$ meter, while the maximum vertical height has reached $(2,96)$ meter and minimum position $(0,58)$ meter. The horizontal distance for left foot instep during the performance of flying stage has reached $(1,52)$ meter, while the maximum vertical height has reached $(2,98)$ meter and minimum position $(1,84)$ meter. The horizontal distance for left foot instep during the performance of landing stage has reached $(1,75)$ meter, while the maximum vertical height has reached $(1,41)$ meter and minimum position $(0,71)$ meter.

It is indicated from table (8) that the horizontal distance for head gravity center during the performance of approaching stage has reached $(0,43)$ meter, while the maximum vertical height has reached $(1,77)$ meter and minimum position $(1,61)$ meter. The horizontal distance for head gravity center during the performance of jumping stage has reached $(0,63)$ meter, while the maximum vertical height has reached $(1,72)$ meter and minimum position $(1,46)$ meter. The horizontal distance for head gravity center during the performance of pushing and lifting stage has reached $(0,88)$ meter, while the maximum vertical height has reached $(1,94)$ meter and minimum position $(0,55)$ meter. The horizontal distance for head gravity center during the performance of flying stage has reached $(1,77)$ meter, while the maximum vertical height has reached $(1,64)$ meter and minimum position $(1,84)$ meter. The horizontal distance for head gravity center during the performance of landing stage has reached $(0,46)$ meter, while the maximum vertical height has reached $(1,61)$ meter and minimum position $(1,13)$ meter. 
Presenting and discussing the results of collected speed for (body gravity center - right foot - left foot - head) of lift skill for aerobic dance gymnasts.

Table (9)

Speed for each of (body gravity center - right foot - left foot - head) of lift skill for aerobic dance gymnasts

\begin{tabular}{|c|c|c|c|c|c|c|c|c|c|}
\hline \multirow[t]{2}{*}{ Frame } & \multirow[t]{2}{*}{ Time } & \multicolumn{2}{|c|}{ C/ Body gravity } & \multicolumn{2}{|c|}{$\mathrm{C} /$ right foot } & \multicolumn{2}{|c|}{ C/ left foot } & \multicolumn{2}{|c|}{ C/ head } \\
\hline & & $\mathbf{X}$ & $\mathbf{Y}$ & $\mathbf{x}$ & $\mathbf{Y}$ & $\mathbf{X}$ & $\mathbf{Y}$ & $\mathbf{X}$ & $\mathbf{Y}$ \\
\hline 1 & 0 & 0.625 & 1.261 & 1.821 & 5.958 & 4.138 & 2.152 & 0.166 & 0.828 \\
\hline 2 & 0.1 & 0.053 & 0.44 & 1.324 & 1.159 & 0.331 & 0.828 & 0.331 & 0.497 \\
\hline 3 & 0.2 & 0.351 & 0.527 & 0.828 & 0.331 & 0 & 0.993 & 0.166 & 0.662 \\
\hline 4 & 0.3 & 0.008 & 1.37 & 0.166 & 2.979 & 0.662 & 0.993 & 0.166 & 0.993 \\
\hline 5 & 0.4 & 0.315 & 0.95 & 0.166 & 1.986 & 0.166 & 0.331 & 0.662 & 0.828 \\
\hline 6 & 0.5 & 0.241 & 0.065 & 0.828 & 1.821 & 0.331 & 0.331 & 0.166 & 0.662 \\
\hline 7 & 0.6 & 0.096 & 0.449 & 0.166 & 1.159 & 0.497 & 0.166 & 0.497 & 0.828 \\
\hline 8 & 0.7 & 0.329 & 2.39 & 1.49 & 6.786 & 0 & 0.993 & 2.317 & 1.49 \\
\hline 9 & 0.8 & 0.211 & 1.086 & 0.166 & 1.655 & 0.331 & 2.317 & 0.497 & 0.331 \\
\hline 10 & 0.9 & 0.353 & 1.296 & 0 & 1.655 & 1.821 & 2.317 & 0.166 & 0.993 \\
\hline 11 & 1 & 0.182 & 2.56 & 1.821 & 2.317 & 6.786 & 10.427 & 0.662 & 0.662 \\
\hline 12 & 1.1 & 0.317 & 0.948 & 0.993 & 1.986 & 0 & 1.159 & 1.655 & 0.497 \\
\hline 13 & 1.2 & 0.414 & 2.34 & 0.828 & 1.821 & 4.8 & 9.269 & 0.993 & 1.655 \\
\hline 14 & 1.3 & 0.399 & 0.725 & 0.828 & 1.324 & 6.62 & 2.979 & 0.497 & 0.662 \\
\hline 15 & 1.4 & 0.435 & 1.8 & 1.655 & 6.62 & 5.296 & 0.166 & 1.821 & 0.331 \\
\hline 16 & 1.5 & 0.526 & 0.647 & 1.986 & 2.979 & 0.331 & 1.159 & 0.993 & 0.166 \\
\hline 17 & 1.6 & 0.84 & 1.557 & 15.392 & 3.641 & 1.324 & 1.49 & 2.814 & 0.166 \\
\hline 18 & 1.7 & 0.011 & 1.015 & 0.662 & 1.159 & 0.662 & 0.828 & 0.331 & 0.497 \\
\hline 19 & 1.8 & 0.633 & 2.583 & 0.662 & 5.958 & 0.993 & 7.944 & 0.497 & 0.828 \\
\hline 20 & 1.9 & 2.021 & 2.278 & 1.655 & 5.462 & 2.317 & 4.303 & 1.49 & 1.655 \\
\hline 21 & 2 & 0.804 & 3.758 & 1.49 & 7.117 & 1.324 & 6.455 & 1.986 & 1.655 \\
\hline 22 & 2.1 & 0.702 & 2.044 & 1.49 & 0.331 & 0.166 & 0.497 & 0.331 & 1.986 \\
\hline 23 & 2.2 & 0.114 & 0.21 & 0 & 0 & 0 & 0 & 1.655 & 1.159 \\
\hline 24 & 2.3 & 0.043 & 0.505 & 0 & 1.821 & 0.662 & 1.159 & 0.166 & 1.655 \\
\hline 25 & 2.4 & 0.081 & 1.901 & 0.497 & 1.986 & 0 & 2.814 & 1.159 & 0.497 \\
\hline 26 & 2.5 & 0.441 & 2.224 & 0.497 & 1.821 & 0.828 & 1.49 & 0.662 & 1.986 \\
\hline 27 & 2.6 & 0.122 & 4.609 & 1.159 & 3.807 & 1.159 & 4.303 & 1.49 & 4.469 \\
\hline
\end{tabular}

It is indicated from table (9) that the values of collected speeds have differed between increase and decline during the motor course for the performance of lift skill for aerobic dance gymnasts, whereas the collected speed for body gravity center during the performance of approaching stage has reached $(0,63 \mathrm{~m} / \mathrm{sec})$, while the maximum speed has reached $(1,37 \mathrm{~m} / \mathrm{sec})$ and minimum speed has reached $(0,44 \mathrm{~m} / \mathrm{sec})$. The collected speed for body gravity center during the performance of jumping stage has reached $(0,35 \mathrm{~m} / \mathrm{sec})$, while the maximum rate for the collected speed has reached $(2,39 \mathrm{~m} / \mathrm{sec})$ and minimum rate for collected speed has reached $(0,07 \mathrm{~m} / \mathrm{sec})$. The collected speed for body gravity center during the performance of pushing and lifting stage has reached $(0,44$ $\mathrm{m} / \mathrm{sec})$, while the maximum rate for the collected speed has reached $(2,56 \mathrm{~m} / \mathrm{sec})$ and minimum speed has reached $(0,71 \mathrm{~m} / \mathrm{sec})$. The collected speed for body gravity center during the performance of flying stage has reached $(2,02 \mathrm{~m} / \mathrm{sec})$, while the maximum rate for the collected speed has reached $(2,58 \mathrm{~m} / \mathrm{sec})$ and minimum speed has reached $(0,65 \mathrm{~m} / \mathrm{sec})$. The collected speed for body gravity center during the performance of landing stage has reached $(0,80 \mathrm{~m} / \mathrm{sec})$, while the maximum rate for the collected speed has reached $(4,61 \mathrm{~m} / \mathrm{sec})$ and minimum speed has reached $(0,21 \mathrm{~m} / \mathrm{sec})$. 
It is also indicated from table (9) that the collected speeds for right foot instep during the performance of approaching stage has reached $(1,82 \mathrm{~m} / \mathrm{sec})$, while the maximum speed has reached $(5,96 \mathrm{~m} / \mathrm{sec})$ and minimum speed has reached $(0,33 \mathrm{~m} / \mathrm{sec})$. The collected speed for right foot instep during the performance of jumping stage has reached $(1,49 \mathrm{~m} / \mathrm{sec})$, while the maximum rate for the collected speed has reached $(6,79 \mathrm{~m} / \mathrm{sec})$ and minimum rate for collected speed has reached $(1,16 \mathrm{~m} / \mathrm{sec})$. The collected speed for right foot instep during the performance of pushing and lifting stage has reached $(1,82 \mathrm{~m} / \mathrm{sec})$, while the maximum rate for the collected speed has reached $(6,62 \mathrm{~m} / \mathrm{sec})$ and minimum speed has reached $(1,32 \mathrm{~m} / \mathrm{sec})$. The collected speed for right foot instep during the performance of flying stage has reached $(15,39 \mathrm{~m} / \mathrm{sec})$, while the maximum rate for the collected speed has reached $(5,96 \mathrm{~m} / \mathrm{sec})$ and minimum speed has reached $(1,16 \mathrm{~m} / \mathrm{sec})$. The collected speed for right foot instep during the performance of landing stage has reached $(1,49 \mathrm{~m} / \mathrm{sec})$, while the maximum rate for the collected speed has reached $(7,12 \mathrm{~m} / \mathrm{sec})$ and minimum speed has reached $(0,33 \mathrm{~m} / \mathrm{sec})$.

It is also indicated from table (9) that the collected speeds for left foot instep during the performance of approaching stage has reached $(4,14 \mathrm{~m} / \mathrm{sec})$, while the maximum speed has reached $(2,15 \mathrm{~m} / \mathrm{sec})$ and minimum speed has reached $(0,33 \mathrm{~m} / \mathrm{sec})$. The collected speed for left foot instep during the performance of jumping stage has reached $(1,82 \mathrm{~m} / \mathrm{sec})$, while the maximum rate for the collected speed has reached $(2,23 \mathrm{~m} / \mathrm{sec})$ and minimum rate for collected speed has reached $(0,17 \mathrm{~m} / \mathrm{sec})$. The collected speed for left foot instep during the performance of pushing and lifting stage has reached $(6,79 \mathrm{~m} / \mathrm{sec})$, while the maximum rate for the collected speed has reached $(10,43 \mathrm{~m} / \mathrm{sec})$ and minimum speed has reached $(0,17 \mathrm{~m} / \mathrm{sec})$. The collected speed for left foot instep during the performance of flying stage has reached $(2,32 \mathrm{~m} / \mathrm{sec})$, while the maximum rate for the collected speed has reached $(7,94 \mathrm{~m} / \mathrm{sec})$ and minimum speed has reached $(0,83 \mathrm{~m} / \mathrm{sec})$. The collected speed for left foot instep during the performance of landing stage has reached $(1,32 \mathrm{~m} / \mathrm{sec})$, while the maximum rate for the collected speed has reached $(6,46 \mathrm{~m} / \mathrm{sec})$ and minimum speed has reached $(0,49 \mathrm{~m} / \mathrm{sec})$.

It is also indicated from table (9) that the collected speeds for the head during the performance of approaching stage has reached $(0,66 \mathrm{~m} / \mathrm{sec})$, while the maximum speed has reached $(0,99 \mathrm{~m} / \mathrm{sec})$ and minimum speed has reached $(0,49 \mathrm{~m} / \mathrm{sec})$. The collected speed for the head during the performance of jumping stage has reached $(2,32 \mathrm{~m} / \mathrm{sec})$, while the maximum rate for the collected speed has reached $(1,49 \mathrm{~m} / \mathrm{sec})$ and minimum rate for collected speed has reached $(0,33 \mathrm{~m} / \mathrm{sec})$. The collected speed for the head during the performance of pushing and lifting stage has reached $(1,82 \mathrm{~m} / \mathrm{sec})$, while the maximum rate for the collected speed has reached $(1,66$ $\mathrm{m} / \mathrm{sec})$ and minimum speed has reached $(0,33 \mathrm{~m} / \mathrm{sec})$. The collected speed for the head during the performance of flying stage has reached $(2,81 \mathrm{~m} / \mathrm{sec})$, while the maximum rate for the collected speed has reached $(1,66 \mathrm{~m} / \mathrm{sec})$ and minimum speed has reached $(0,17 \mathrm{~m} / \mathrm{sec})$. The collected speed for the head during the performance of landing stage has reached $(1,99 \mathrm{~m} / \mathrm{sec})$, while the maximum rate for the collected speed has reached $(4,45 \mathrm{~m} / \mathrm{sec})$ and minimum speed has reached $(0,49 \mathrm{~m} / \mathrm{sec})$. 
- Presenting and discussing the results of pace chronogram in order to demonstrate the time distribution (composition) of lift skill for aerobic dance gymnasts.

\begin{tabular}{c|c|c|c|c|c}
\hline \hline Player & \multicolumn{4}{|c}{ Technical stages of lift skill for world class aerobic dance gymnasts } \\
\hline \hline Form & Approach & Jumping & Pushing and lifting & Flying & Landing \\
& $0,4 \mathrm{sec}$ & $0,5 \mathrm{sec}$ & $0,5 \mathrm{sec}$ & $0,5 \mathrm{sec}$ & $0,7 \mathrm{sec}$ \\
\hline Prior & Approach & Jumping & Pushing and lifting & Flying & Landing \\
sample & $2,10 \mathrm{sec}$ & $0,5 \mathrm{sec}$ & $0,30 \mathrm{sec}$ & $0,5 \mathrm{sec}$ & $0,5 \mathrm{sec}$ \\
\hline Post sample & Approach & Jumping & Pushing and lifting & Flying & Landing \\
& $0,4 \mathrm{sec}$ & $0,5 \mathrm{sec}$ & $0,5 \mathrm{sec}$ & $0,5 \mathrm{sec}$ & $0,7 \mathrm{sec}$ \\
\hline \hline
\end{tabular}

Shape (2) pace chronogram to demonstrate the time distribution of lift skill for aerobic dance gymnasts.

It is indicated from shape (2) that lift skill for aerobic dance gymnasts (form) has taken a time period that reached $(2,5)$ second, while it was for sample $(3,9)$ second in prior measurement, while it reached $(2,6)$ second in post measurement with improvement difference $(1,3)$ for the post measurement.

As for stage of (approaching) for the form, it has taken $(0,4 \mathrm{sec}$.), while it has reached $(2,10 \mathrm{sec}$.) for prior measurement for study sample, whereas here the extent of approaching speed of Egyptian player is clearly indicated, as well as lack of using the transition speed in this stage. While the post measurement has reached $(0,4$ sec.) equal to the form. The jumping stage has reached $(0,5 \mathrm{sec})$ (for the form) equal to study sample in both the prior and post measurement. While the stage of lifting and pushing has reached $(0,5 \mathrm{sec})$ (form), as the sample in prior measurement was $(0,3 \mathrm{sec}$.) and the shortfall of pushing and lifting time of the sample from the form is shown, which indicates the lack of complete push for study sample in prior measurement. While the pushing and lifting stage has reached $(0,5 \mathrm{sec}$.) for post measurement. As for flying stage, it equaled both the form and sample in prior and post measurement, as it reached $(0,5 \mathrm{sec}$ ), while the landing time reached $(0,7 \mathrm{sec})$ (for the form), as it has reached $(0,5 \mathrm{sec})$ for the sample in prior measurement, as for post measurement, it has reached $(0,7 \mathrm{sec}$. 
- Presenting and discussing the results of arithmetic average and standard deviation of lift skill for aerobic dance gymnasts.

$$
\text { Table (10) }
$$

Presenting and discussing results of arithmetic average and standard deviation of lift skill for aerobic dance gymnasts.

\begin{tabular}{|c|c|c|c|c|c|c|}
\hline \multirow{2}{*}{ No. } & \multirow{2}{*}{ Tests } & \multirow{2}{*}{$\begin{array}{c}\text { Measurement } \\
\text { unit }\end{array}$} & \multicolumn{2}{|c|}{ Prior measurement } & \multicolumn{2}{|c|}{ Post measurement } \\
\hline & & & $\begin{array}{l}\text { Arithmetic } \\
\text { average }\end{array}$ & $\begin{array}{l}\text { Standard } \\
\text { deviation }\end{array}$ & $\begin{array}{l}\text { Arithmetic } \\
\text { average }\end{array}$ & $\begin{array}{l}\text { Standard } \\
\text { deviation }\end{array}$ \\
\hline 1 & $\begin{array}{l}\text { Shuttle running for } \\
\text { the distance of } 54 \mathrm{~m}\end{array}$ & Second & 19.91 & 3.50 & 11.21 & 1.19 \\
\hline 2 & $\begin{array}{l}\text { Fixed balance } \\
\text { measurement }\end{array}$ & Second & 8.98 & .50 & 12.79 & .43 \\
\hline 3 & $\begin{array}{l}\text { Bending the torso in } \\
\text { front below from } \\
\text { standing }\end{array}$ & Meter & 11.75 & 2.10 & 21 & 2.47 \\
\hline 4 & $\begin{array}{l}\text { Wide jump from } \\
\text { stable position }\end{array}$ & Meter & 1.64 & .27 & 2.41 & 0.09 \\
\hline 5 & $\begin{array}{l}\text { Sitting from running } \\
\text { for } 30 \text { seconds }\end{array}$ & number & 15.62 & 4.53 & 19.5 & 4.01 \\
\hline 6 & Hanging & Second & 7.912 & 1.47 & 19.11 & 2.31 \\
\hline 7 & $\begin{array}{l}\text { Shuttle running for } \\
\text { the distance of } 9 \mathrm{~m}\end{array}$ & Second & 6.72 & 3.51 & 4.11 & 0.475 \\
\hline 8 & $\begin{array}{c}\text { Diagonal face down } \\
\text { from standing } \\
\text { position }\end{array}$ & number & 13.75 & 2.82 & 20.87 & 4.69 \\
\hline 9 & $\begin{array}{c}\text { Running } 30 \mathrm{~m} \text { from } \\
\text { slow start }\end{array}$ & Second & 6.24 & .11 & 4.355 & $\mathbf{0 . 0 0}$ \\
\hline 10 & Total level & Degree & 0.5 & 0.134 & 0.9 & 0.364 \\
\hline
\end{tabular}

It is indicated from table (10), the presence of statistical indication between the prior and post measurement for the experimental group in terms of physical variations and skill performance level subject matter of research, whereas the calculated value $(Z)$ was higher than its table value at moral level $(0,05)$, which indicates the improvement of the experimental group in these variations with statistically indicative degree. 
Presenting and discussing the results of differences indication between the prior and post measurement of lift skill for aerobic dance gymnasts.

$$
\text { Table (11) }
$$

Presenting and discussing the results of differences indication between the prior and post measurement of lift skill for aerobic dance gymnasts

\begin{tabular}{|c|c|c|c|c|c|c|c|c|}
\hline No. & $\begin{array}{l}\text { Variables } \\
\text { Tests }\end{array}$ & $\begin{array}{c}\text { Measurement } \\
\text { unit }\end{array}$ & Direction & No. & $\begin{array}{c}\text { Rank } \\
\text { average }\end{array}$ & $\begin{array}{c}\text { Rank } \\
\text { total }\end{array}$ & $\begin{array}{l}\text { "Y" } \\
\text { value }\end{array}$ & $\begin{array}{l}\text { Risk of } \\
\text { error }\end{array}$ \\
\hline \multirow{4}{*}{1} & \multirow{4}{*}{$\begin{array}{l}\text { Shuttle running for } \\
\text { the distance of } 54 \\
\text { m }\end{array}$} & \multirow{4}{*}{ Second } & - & $\overline{0}$ & $\overline{0.00}$ & $\overline{0.00}$ & \multirow{4}{*}{$-2.524-$} & \multirow{4}{*}{.012} \\
\hline & & & + & 12 & 4.50 & 36.00 & & \\
\hline & & & $=$ & $\mathbf{0}$ & & & & \\
\hline & & & Total & 12 & & & & \\
\hline \multirow{4}{*}{2} & \multirow{4}{*}{$\begin{array}{l}\text { Fixed balance } \\
\text { measurement }\end{array}$} & \multirow{4}{*}{ Second } & - & 12 & 4.50 & 36.00 & \multirow{4}{*}{-2.524} & \multirow[t]{4}{*}{.012} \\
\hline & & & + & $\mathbf{0}$ & 0.00 & 0.00 & & \\
\hline & & & $=$ & $\mathbf{0}$ & & & & \\
\hline & & & Total & 12 & & & & \\
\hline \multirow{2}{*}{3} & \multirow{2}{*}{$\begin{array}{c}\text { Bending the torso } \\
\text { in front below from } \\
\text { standing }\end{array}$} & \multirow{2}{*}{ Meter } & - & $\mathbf{0}$ & 0.00 & 0.00 & \multirow{2}{*}{ 2.536- } & \multirow[t]{2}{*}{.011} \\
\hline & & & Total & 12 & & & & \\
\hline \multirow{3}{*}{4} & \multirow{3}{*}{$\begin{array}{l}\text { Wide jump from } \\
\text { stable position }\end{array}$} & \multirow{3}{*}{ Meter } & - & $\mathbf{0}$ & 0.00 & 0.00 & \multirow{3}{*}{-2.524} & \multirow{3}{*}{.012} \\
\hline & & & + & 12 & 4.50 & 36.00 & & \\
\hline & & & $\begin{array}{l}= \\
\text { Total }\end{array}$ & \begin{tabular}{l|l}
0 \\
12
\end{tabular} & & & & \\
\hline \multirow{3}{*}{5} & \multirow{3}{*}{$\begin{array}{l}\text { Sitting from } \\
\text { running for } 30 \\
\text { seconds }\end{array}$} & \multirow{3}{*}{ number } & - & $\mathbf{0}$ & 0.00 & 0.00 & \multirow{3}{*}{-2.585} & \multirow{3}{*}{.010} \\
\hline & & & + & 12 & 4.50 & 36.00 & & \\
\hline & & & $\begin{array}{l}= \\
\text { Total }\end{array}$ & 0 & & & & \\
\hline \multirow{4}{*}{6} & \multirow{4}{*}{ Hanging } & & - & 0 & 0.00 & 0.00 & & \\
\hline & & Second & + & 12 & 4.50 & 36.00 & & .010 \\
\hline & & Second & $=$ & $\mathbf{0}$ & & & -2.585 & \\
\hline & & & Total & 12 & & & & \\
\hline & & & - & $\mathbf{0}$ & 0.00 & 0.00 & & 011 \\
\hline 7 & Shuttle running for & Second & + & $\frac{12}{0}$ & 4.50 & 36.00 & -2.539 & \\
\hline & & & Total & 12 & & & & \\
\hline & Diagonal face & & - & $\mathbf{0}$ & 0.00 & 0.00 & & \\
\hline 8 & down from & number & + & 12 & 4.50 & 36.00 & $-2.530-$ & .011 \\
\hline & standing position & & $=$ & $\mathbf{0}$ & & & & \\
\hline & & & Total & 12 & & & & \\
\hline & & & - & 0 & 0.00 & 0.00 & & .008 \\
\hline 9 & $\begin{array}{l}\text { Running } 30 \mathrm{~m} \\
\text { from slow start }\end{array}$ & Second & $\begin{array}{l}+ \\
=\end{array}$ & 12 & 4.50 & 36.00 & $-2.640-\mathrm{b}$ & \\
\hline & & & Total & 12 & & & & \\
\hline & & & - & $\mathbf{0}$ & 0.00 & 0.00 & & 009 \\
\hline 10 & Total level & Deoree & & & & & -3.459 & .006 \\
\hline 10 & otar iever & Degiee & $=$ & & & & -0.400 & \\
\hline & & & Total & & & & & \\
\hline
\end{tabular}

Table value of "Y" at moral level of 0.05 is 1.96

It is indicated from table (11) related to the differences indication between the prior and post measurement in physical and skill tests subject matter of the research, whereas the researchers have concluded that there are statistically indicative differences between the prior and post measurement and for the interest of post measurement in the tests subject matter of research, whereas the value of calculated "Y" is bigger than "Y" table value at moral level 0.05. 
Presenting and discussing the results of improvement rate between the prior and post measurement of lift skill for aerobic dance gymnasts.

Table (12)

Presenting and discussing the results of improvement rate between the prior and post measurement of lift skill for aerobic dance gymnasts.

\begin{tabular}{|c|c|c|c|c|c|}
\hline No. & Tests & $\begin{array}{l}\text { Measurement } \\
\text { unit }\end{array}$ & $\begin{array}{c}\text { Prior } \\
\text { measurement }\end{array}$ & $\begin{array}{c}\text { Post } \\
\text { measurement }\end{array}$ & $\begin{array}{l}\text { Improvement } \\
\text { rate }\end{array}$ \\
\hline 1 & $\begin{array}{l}\text { Shuttle running for the } \\
\text { distance of } 54 \mathrm{~m}\end{array}$ & Second & 19.91 & 11.21 & $\% 43.66$ \\
\hline 2 & Fixed balance measurement & Second & 8.98 & 12.79 & $\% 42.36$ \\
\hline 3 & $\begin{array}{l}\text { Bending the torso in front } \\
\text { below from standing }\end{array}$ & Meter & 11.75 & 21 & $\% 78.72$ \\
\hline 4 & $\begin{array}{l}\text { Wide jump from stable } \\
\text { position }\end{array}$ & Meter & 1.64 & 2.41 & $\% 47.10$ \\
\hline 5 & $\begin{array}{l}\text { Sitting from running for } 30 \\
\text { seconds }\end{array}$ & number & 15.6 & 19.5 & $\% 24.8$ \\
\hline 6 & Hanging & Second & 7.91 & 19.1 & $\% 141.6$ \\
\hline 7 & $\begin{array}{l}\text { Shuttle running for the } \\
\text { distance of } 9 \mathrm{~m}\end{array}$ & Second & 6.72 & 4.11 & $\% 38.8$ \\
\hline 8 & $\begin{array}{l}\text { Diagonal face down from } \\
\text { standing position }\end{array}$ & number & 13.75 & 20.8 & $\% 51.81$ \\
\hline 9 & $\begin{array}{c}\text { Running } 30 \mathrm{~m} \text { from slow } \\
\text { start }\end{array}$ & Second & 6.24 & 4.35 & $\% 30.20$ \\
\hline 10 & Total level & Degree & 0.5 & 0.9 & $\% 80$ \\
\hline
\end{tabular}

Results of table (12) related to the change rate in post measurement from the prior measurement for the tests subject matter of research, until the improvement percentage of post measurement from the prior measurement is reached, whereas the researcher used improvement percentage test.

\section{- Discussing the results of third assumption subject matter of research}

It is indicated from table (10) the presence of difference with statistical indication between the prior and post measurement for the interest of post measurement in physical variations and skill level performance subject matter of research, whereas the calculated $(Z)$ value was higher than its table value at moral level $(0,05)$, which indicates improvement in these variations with statistical indication. These results related to the statistical indications regarding the measurements of physical variables of skillful performance of the skill subject matter of research (shuttle running for $54 \mathrm{~m}$, measurement of fixed balance, bending the torso forward down from standing, wide jumping from fixity, sitting from running for $30 \mathrm{sec}$., hanging, shuttle running for the distance of $9 \mathrm{~m}$, inclined face down from standing, running $30 \mathrm{~m}$ from slow start), the measurements of this group have improved in post measurement from prior measurement with differences with statistical indication at level of $(0,05)$. The improvement at the end of the proposed program from its start in all measurements of physical variables has reflected the program impact on the improvement of measurements level of physical variable related to the skill subject matter of research, which were based upon some techniques and training for skillful performance.

It is indicated from table (11) related to the indication of differences between prior and post measurement in physical and skill tests subject matter of research, whereas the researchers have concluded that there are differences with statistical indication between the prior and post measurement and for the interest of post measurement in test subject matter of research, whereas the calculated $(Z)$ value is bigger than $(Z)$ table value at moral level 0.05 , whereas $(Z)$ table value at moral level $(0,05)=1,96$. Which indicates that there are differences with statistical indication between the post and prior measurement for the interest of post measurement. Also the results of table 
(12) indicates that "the improvement percentage" between the prior and post measurement in physical variable are for the interest of post measurement in all physical variable measurements, whereas the improvement rate in test of shuttle running distance for $54 \mathrm{~m}$ has reached $43.66 \%$ for the interest of post measurement, while improvement percentage in tests of fixed balance measurement has reached $42.36 \%$ for the interest of post measurement, while the improvement rate in test of bending the torso forward below was $78.72 \%$ for the interest of post measurement, as the improvement rate in test of wide jumping from fixity was 47.10 or the interest of post measurement, whereas the improvement rate in test of sitting from running for $30 \mathrm{sec}$. has reached $24.8 \%$ for the interest of post measurement, while the improvement rate in hanging test has reached $141.6 \%$ for the interest of post measurement, where the improvement rate in shuttle running test for the distance of 9 shuttle running test for the distance of $9 \mathrm{~m}$ has reached $38.8 \%$, as the test of inclined face down from standing has improved with $51.81 \%$, and the test of running from slow start has improved with $30.20 \%$, while the skill level for the whole movement was improvement was improved with rate of $80 \%$ for the interest of post measurement.

The results of this research are consistent with the opinions of Heba Saad Muhammad (2010), Hazem Hassan Abdullah (2008), Saeed Muhammad Ghoneim (2008) Iman Abdullah Al-Aasar (2007), Amal Muhammad Zakaria (2007), Yahya Muhammad Zakaria (2006), That the various training programs for skill performance have a "positive" effect in raising the level of measurements of physical variables and skill performance of the skill(s) subject matter of research. (20) (5) (6) (2) (3) (21)

Based upon the aforementioned, it is indicated that the validity of third assumption for the research has been achieved, which states the effects of the training program on the physical and skill variables subject matter of the research.

\section{- Conclusions:}

1- The time of (overall performance) of lift skill for aerobic dance gymnasts has taken period of time that reached $(2,6)$ sec., time of (approaching) stage reached $(0,4)$ sec., the time of stage of (jumping), (pushing and lifting), and (flying) has reached $(0,5)$ sec., while the time of (landing) stage has taken $(0,7)$ sec.

2- The maximum height reached by the highest point in the body is (instep), which has reached (3.06) meters in the flying stage, while each of (right instep), (body gravity center), during the performance of the skill has reached $(2,98)$ meters, $(2,28)$ meters, respectively.

3- The maximum speed rate was for the right foot in start of flying stage, which reached $(15.39 \mathrm{~m} / \mathrm{s})$.

4- The performance trainings affected the improvement of stage and overall time of performing the lift skill for the aerobic dance gymnasts, where the average improvement in the total time reached (1.3) sec.

5- There is an apparent improvement in the physical abilities chosen to measure (strength - ability - flexibility) after applying the trainings.

6- The exercises achieved a clear improvement in the hanging test by $141.6 \%$ in favor of post-measurement, which is reflected in the performance of the lift skill of aerobic dance gymnasts.

\section{- Recommendations:}

1- Be guided by the indicators related to the kinematic characteristics of the skill's performance, which will be reflected in the development of the technical performance of the players.

2- Use of targeted trainings to perform the lift skill of aerobic dance gymnasts as an effective training method in development of physical abilities.

3- Directing the results of this study and the used program to the trainers in the field of aerobic gymnastics training in order to benefit therefrom in the training operations.

4- Dependence on the anatomical and technical analysis of different skills when developing training programs that depend on the use of specific exercises.

5- The importance of using biomechanical studies and kinetic analysis of skills in activities in general and aerobic gymnastics sport in particular as a basis for developing special trainings for the type of skill used, which could contribute to the increase in the level of skills. 
6- Establishment of specific trainings for each stage of the skill (introductory - basic - final) as well as linking them.

7- Using kinetic analysis to learn the details of remainder of the skills, in addition to development of appropriate trainings therefor, and how to train them, in order to perform them at the highest possible efficiency and with minimal effort.

\section{References:}

First: Arabic References:

1 Ibrahim Ahmed Salama

2 Eman Abdullah Al-Aasar

3 Amal Mohamed Zakaria

$4 \quad$ Belal Morsi Witwit

5 Hazem Hassan Abdullah

6 Saeed Mohammed Ghanimi

$7 \quad$ Talha Hussein Husam Al-Din

8

9 Talha Hussein Hussam E1 Dein and others

10 Adel Abdul-Basir

11 Owais Ali al-Jabali
Applied entry to the measurement in physical fitness, Monchaat $\mathrm{Al}$ Maaref, 2000.

The effect of specific training on the level of performance of the motor endings of gymnastics, the scientific journal of physical education sciences, the third issue, Faculty of Physical Education for Girls, Alexandria University 2007.

The effect of specific training program on the level of performance of the front flop skill on the hands on the jumping horse, Master Thesis (unpublished), College of Physical Education for Girls, Helwan University 2007.

Guided trainings in the light of the electrical activity of the muscles and the kinematic characteristics of the reverse waist grab skill and its effect on the physical and skill level of the wrestlers, the Scientific Journal of Sports Science and Arts, Faculty of Physical Education for Girls on the Jazirah, Egypt 2015.

The effect of specific training on raising the skill level of gymnast kids under (6) years, the scientific journal of physical education sciences, issue thirty-four, Faculty of Physical Education for Girls, Alexandria University 2008.

The effect of using plyometric training with tools on developing special explosive force to improve the technical performance of the front flop on a jumping horse, Master Thesis (unpublished), Faculty of Physical Education for Boys, University of Alexandria, 2008.

Specific exercises and their relationship to the level of motor achievement in gymnastics, the scientific journal of physical and sports education, researches of the future vision conference for physical and sports education in the Arab world, second volume, the Faculty of Physical Education for Boys, Helwan University 1993.

Biomechanics - Theoretical and Applied Foundations, First Edition, Dar Al-Fikr Al-Arabi, Cairo, 1993.

Applied Kinesiology, Part One, First Edition, The Book Center for Publishing 1998.

Theories and scientific basis in training of modern gymnastics, first part, Dar Al-Fikr Al-Arabi, Cairo 1998.

Mathematical training between theory and training, Dar G. M. M. 2000. 
12 Fathi Ahmed Ibrahim

13 Mohamed Ibrahim Shehata Ahmed Fouad Al-Shazly

14 Mohamed El Sayed Khalil

15 Muhammad Jaber Bareeqa, Khairiah Ibrahim Al Sokary

16

17 Muhammad Hassan Allawi, Muhammad Nasruddin Radwan

18 Muhammad Subhi Hassanin

19 Mustafa Al-Sayeh Muhammad, Salah Anas Muhammad

20 Heba Saad Mohamed

21 Yahya Mohammed Zakaria
Scientific principles and foundations for physical exercises and sports shows, Dar Al-Wafa for Publication, Alexandria 2008.

Field applications of motor analysis in gymnastics, Egyptian Library, Louran, Alexandria 2006.

Assessment and Measurement (Theories and Applications), 6th of October Library, Mansourah 2008.

Basic Principles of Biomechanics in sport Field (Qualitative Analysis), Part Two, Monchaat Al Maaref, Alexandria 2010.

Basic Principles of Biomechanics in the Mathematical Field, Part 1, Monchaat Al Maaref, Alexandria 2002.

Kinetic performance tests, 3rd edition, Dar Al-Fikr Al-Arabi, Cairo, 2001.

Measurement and assessment in Physical Education, Second Edition, Dar Al-Fikr Al-Arabi, Cairo, 2003.

European Fitness Eurovet Test, Matbaeat Al'iisheae Al faniya, Alexandria, 2000.

Using the kinematic rhythm to learn some horse jumping skills in gymnastics for students of the Faculty of Physical Education, Minia University, PhD Thesis (unpublished), Faculty of Physical Education, Minia University 2010.

The effect of a proposed mental training program supported by virtual reality models on developing some psychological skills and improving the technical performance of the front flop on the arms on the horse jumping device, Theories and Applications Journal, Fifty-ninth Issue, Faculty of Physical Education for Boys, University of Alexandria 2006.

\section{Second: English References:}


22 Aerobick Gymnastic

23 Dong Xin-jun,Diao Zaizhen

24 Elfi Schlegel, Claire Ross Dunn

25 GREGORY D. MYER,1 KEVIN R . FORD,1 federation in ternatinale de Gymnastique 2017-2020

The competitive Prospect and main Characteristics of new Regulation Changing of International Athletic Aerobics Gymnastics, Journal of Guangzhou Physical Education Institute 2005

The young performer's guide to gymnastics, 2 nd, firefly books (U.S) inc ,new york ,U S A 2007.

Neuromuscular Training Improves Performance And lower-

Extremity Biomechanics In Female Athletes, Journal of Strength and Conditioning Research, 2005. 